\title{
Local and regional strategies for rebuilding fisheries management institutions in coastal British Columbia: what components of comanagement are most critical?
}

\author{
$\underline{\text { Evelvn Pinkerton }}^{1}$, Eric Angel $^{1}, \underline{\text { Neil Ladell }}^{1}, \underline{\text { Percy Williams }}^{2}$, Midori Nicolson $^{3}, \underline{\text { Jov Thorkelson }}^{4}$ and $^{\text {Henry Clifton }}{ }^{5}$
}

\begin{abstract}
Aboriginal and nonaboriginal fishing-dependent communities on the coast of British Columbia, Canada, having lost traditional fisheries management institutions along with significant fishing opportunity, are in the process of rebuilding local and regional institutions to allow their survival. Sometimes, the rebuilding effort involves the creation of largely new institutions. It can also involve the reactivation, reinvention, or repositioning of older ones. We consider the aspirations, strategies, and activities of organizations in two regions of the coast involved in two different fisheries: salmon on the north coast and intertidal clams in the Broughton Archipelago. We analyze what the two regions have in common, as well as their differences, to generate general predictions and recommendations about what preconditions appear to be necessary for success in rebuilding institutions in communities and regions at these scales and what actions are likely to be most effective, according to a body of literature on self-management and comanagement. In both cases, we found favorable conditions in the communities, the external political arena, and in government to support the rebuilding goals of the organizations working in the two regions. Although both areas would benefit from greater financial resources, the most critical need is for external support in the form of alliances, issue networks, and access to multiple sources of power.
\end{abstract}

Key Words: clams; fisheries comanagement; necessary conditions; regional institutions; salmon

\section{INTRODUCTION}

Over the last four decades, long-established aboriginal and nonaboriginal fishing communities on the British Columbia (BC) coast have been undergoing radical loss of fishing licenses, vessels, and opportunity, and also of the government presence and infrastructure that formerly supported local fishing activities. These losses have been concentrated in more rural and northern regions of the province (Ecotrust 2004), the very regions that are most dependent on fishing livelihoods, have the fewest occupational alternatives, and hold the largest number of aboriginal fishers who in theory enjoy constitutionally protected access rights. These losses resulted directly and indirectly from government policies seeking to rationalize, i.e., reduce, the number of licenses and vessels to reduce fishing pressure in response to conservation concerns and to meet economic objectives of improving the financial viability of fishing enterprises, allowing for what the government perceived as more effective management (Fisheries and Oceans Canada 1990).

Before we contemplate rebuilding local and regional fisheries management institutions, we must first consider the full nature and extent of these losses. Maritime resources, fishing and salmon in particular, were the backbone of the economy, society, and culture of Pacific Northwest peoples for upwards of 10,000 years (Inglis and MacDonald 1979, Muckle 2007). This fundamental social-ecological relationship held true in rural coastal BC until the final decade of the 20th century, in spite of enormous upheaval and loss occasioned by nonaboriginal settlement in the region over the past 150 years (Barman 1991, Newell 1993, Harris 2008, Turner et al. 2013).

Since the late 1960s, the federal government in Canada has been unwinding the social contract that made Canadian sovereignty of the Pacific coast from Washington State to Alaska a reality in the first place. For example, when First Nations on the BC coast were allocated reserves by government negotiators roughly a hundred years ago, they received miniscule allotments relative to their traditional territories, notwithstanding the objections of aboriginal people to the process and the results (Harris 2008). The logic of government negotiators was that aboriginal people would support themselves by fishing (Pinkerton 1987, Ommer 2007). After World War I, returning Canadian soldiers were encouraged to settle on the north coast of $\mathrm{BC}$ in return for fishing licenses (Marchak et al. 1987, Meggs 1991). Both of these contracts have now been abandoned by government, starting with the Davis Plan's elimination of all boats delivering less than $\$ 2500$ worth of fish per year.

The goals of this discussion are to (1) consider what the comanagement literature says about critical conditions necessary for successful local institutional rebuilding; (2) identify what institutional losses have occurred as a consequence of this policy direction; (3) examine the vision, strategies, and actions being taken in two regions of the $\mathrm{BC}$ coast where organizations are building or rebuilding institutions to retain and reclaim access and management rights to their local fisheries; and (4) consider what communities interested in rebuilding their institutions can learn from experiences elsewhere, e.g., with what priorities might particular strategies be effective?

\section{THEORY AND METHODS}

\section{What does comanagement contribute to rebuilding collapsed institutions or their alternatives, and why is it important to rebuild?}

We begin with a brief consideration of what the comanagement literature contributes to insights regarding rebuilding collapsed institutions or their alternatives. From the late 1970s onward, an

${ }^{1}$ Simon Fraser University, ${ }^{2}$ Gwayasdums, BC, ${ }^{3}$ Land \& Marine Resources Director, Dzawadaenuxw First Nation, ${ }^{4}$ United Fishermen and Allied Workers Union-UNIFOR, ${ }^{5}$ Native Brotherhood of British Columbia 
older literature from anthropology and ecology on the selfregulating capacities of contemporary fishing communities (Acheson 1975, Berkes 1981) has been integrated into a newer literature on the benefits of power sharing between self-regulating communities and government agencies (Pinkerton 1989, Wilson et al. 1994, Pinkerton and Weinstein 1995, Wilson et al. 2003, Armitage et al. 2007). We consider comanagement to be power sharing that involves not only access and withdrawal rights (operational level), but also higher-level rights such as harvest management, exclusion, and coordination with other users (collective choice). Given the legal mandate of the Canadian federal government to manage fisheries, the necessity of coordinating actions with neighbors, and conflicting uses of fish, e.g., commercial, aboriginal, and recreational fisheries, and marine space, e.g., tourism, shipping, aquaculture, and oil and gas development, self-regulation obviously requires coordination with and integration into comanagement arrangements between local/ regional institutions and the Canadian Department of Fisheries and Oceans (DFO).

Any institutional capacity lacking in one of these power-sharing entities has to be supplied by another. In a resource system like BC's fisheries, in which the senior level of government has both the constitutional authority and fiscal ability to dictate the terms under which fisheries management is carried out, the scope for comanagement is limited unless government chooses to embrace that option. In recent years, with the reduction in fishermen's union membership associated with the loss of fishing licenses, the most important check on DFO's exercise of authority is the existence of legally protected aboriginal rights to subsistence and, to a lesser degree, commercial fisheries (Ahousaht First Nation vs. Canada 2007, Ahousaht et al. vs. Canada 2013). The exercise of these rights is restrained by the limited financial, administrative, and technical resources in most aboriginal coastal communities in northern BC and in the Broughton Archipelago off northern Vancouver Island. However, beginning in the late 1990s (Lane and Stephenson 2000), federal government cutbacks and legislative changes, most recently in the Jobs, Growth and Long-term Prosperity Act and the Jobs and Growth Act of 2012, have undermined DFO's capacity and weakened its legitimacy. This has created an opportunity for institutional rebuilding along comanagement lines, as illustrated in our two case studies.

In the context of these changes to the DFO, the rebuilding or creation of local management institutions could become the foundation for potentially enduring comanagement relationships, both among regional organizations or communities that must work together and between regionally based groups and the DFO. The literature cited above documents important contributions to fisheries management by rebuilt institutions (Pinkerton 1989, Wilson et al. 1994, Pinkerton and Weinstein 1995, Wilson et al. 2003, Armitage et al. 2007), including (1) a higher degree of trust between fishermen's organizations and government and greater willingness on the part of government to allow fishermen's organizations to undertake a range of self-management responsibilities; (2) a willingness among both fishing communities and government to share data and local knowledge about the resource and, therefore, to reach collectively a more complete understanding of the resource; (3) a willingness among both fishermen's organizations and government to explore more effective options for regulation and enhancement; (4) an improved ability to develop and successfully enforce regimes that fishermen perceive as appropriate and legitimate; (5) development of fisheries with greater equity, effectiveness, and legitimacy, and thus greater compliance, in fishermen's organizations and communities; and (6) reduced costs of health care, welfare, and unemployment because more fishermen will be actively involved in management and fishing activities. The last improvement might not affect the senior government department managing fisheries, but it would have significant impacts on the costs of health care and welfare borne by other government departments. It has been well documented that aboriginal communities able to pursue traditional livelihoods and experience cultural continuity have fewer health problems and lower suicide rates (Chandler and Lalonde 2009, Campbell et al. 2011), resulting in lower costs to government.

The research reported here was funded by two different Canadian scholarly programs, both of which supported research founded on partnerships with coastal communities or organizations. The research in case study 1 was funded by a Natural Science and Engineering Research Council industry-driven grant undertaken with the Canadian Council of Professional Fish Harvesters (the Canadian Fisheries Research Network, http://www.cfrn-rcrp.ca/ Public-Home-EN); case study 1 included an agreement between the United Fishermen and Allied Workers Union (UFAWU, now amalgamated with UNIFOR: UFAWU-UNIFOR) and university researchers. The north coast regional focus of this study took in a diverse range of aboriginal and nonaboriginal communities, governments, and fishing organizations. The information presented in case study 1 draws from a combination of informal interviews, participant observation (2010-2013), and data from secondary sources.

The research in case study 2 was funded by a Social Science and Humanities Research Council Partnership Development Grant to Simon Fraser University and the Musgamagw Dzawada'enuxw Tribal Council, comprising four Kwakwaka'wakw tribes. The focus in this study was on a much smaller region than the first case, consisting entirely of aboriginal, i.e., First Nations, communities. Case study 2 drew primarily from semistructured interviews with 14 community members, as well as participant observation in 2012 and data from secondary sources.

In both cases the nonuniversity partners played a major role in defining the research goals and are working with the university partners to achieve those goals. These two cases illustrate a range of institutional rebuilding strategies at different geographic and membership scales, degrees of membership diversity, breadth of issues, types of rights, complexity of species mix, and stages of development.

\section{CASE STUDY 1: THE SUSTAINABLE MARINE FISHERIES AND COMMUNITIES ALLIANCE ON THE BC NORTH COAST}

\section{Institutional losses in the north coast salmon fishery}

As nonaboriginal workers and settlers put down roots on the north coast over the course of the last century, they, like aboriginal peoples, were sustained by harvesting the year-round abundance of marine resources in the area. Salmon, halibut, and herring were the preeminent cash and food sources; other groundfish species, eulachon, shellfish, and seaweeds filled in the seasonal round 
Table 1. Skeena River sockeye salmon (Oncorhynchus nerka) harvest trends, 1973-2012 (Pacific Salmon Commission 2011, 2012, English 2012, English et al. 2012; Skeena Salmon Program 2012, unpublished data). FSC is First Nations' harvest for food, social, and ceremonial purposes.

\begin{tabular}{|c|c|c|c|c|c|c|c|}
\hline Decade & Total Run & Alaska harvest & $\begin{array}{c}\text { Return to } \\
\text { Canada }\end{array}$ & FSC & Marine harvest & $\begin{array}{l}\text { In-river } \\
\text { harvest }\end{array}$ & Uncategorized harvest \\
\hline 1973-1982 & $2,439,040$ & 152,071 & $2,286,970$ & $\mathrm{n} / \mathrm{a}$ & 988,905 & $\mathrm{n} / \mathrm{a}$ & 344,575 \\
\hline 1983-1992 & $3,129,230$ & 406,041 & $2,723,188$ & 149,067 & 964,935 & $\mathrm{n} / \mathrm{a}$ & 429,969 \\
\hline 1993-2002 & $3,671,018$ & 390,085 & $3,280,213$ & 138,872 & $1,274,184$ & 248,320 & 379,425 \\
\hline 2003-2012 & $1,830,790$ & 144,129 & $1,686,661$ & 142,215 & 346,526 & 128,789 & 84,459 \\
\hline
\end{tabular}

(Muckle 2007, Angel 2011). Extraction industries like forestry and mining had their moments, booms, and busts, as befits a commodity-driven economy, but life on the north coast continued to revolve around fishing as the primary activity (Meggs 1991, Rajala 2006). In parallel, many of the important local institutions belonged to fishermen, including province-wide organizations like the UFAWU and the Native Brotherhood of BC. Both developed strong reciprocal ties to north coast communities. The UFAWU and the Brotherhood drew heavily on Prince Rupert and environs for members, often in competition with one another (Drucker 1958). In return, they trained several generations of community leaders: mayors, chiefs, councilors, businessmen, and educators.

The large membership of the two organizations made for considerable influence in the fishing industry (Lyons 1969, North 1974, Meggs 1991). In addition to negotiating prices with the processing companies and taking their members out on strike if necessary, the UFAWU and the Native Brotherhood of BC had a voice in the management of the fishery through their participation in an advisory body called the Skeena River Salmon Management Committee. Established by the DFO in the early 1960s (Wright 2010), the committee is what we would now recognize as an early-stage comanagement institution. Meeting several times a year, commercial, recreational, and aboriginal representatives had an opportunity to review, comment on, and challenge fishing plans and regulations, stock assessments, habitat protection and enhancement, and catch and landings data, which represent a substantial range of fisheries management functions. Indeed, the committee and its successor, the North Coast Advisory Board, developed over the decades into important regional institutions in their own right (UFAWU-UNIFOR, Prince Rupert office, personal communication).

In the mid-1990s, amidst a climate of fiscal retrenchment and heightened environmental concern, the federal government began to overhaul its management of salmon fisheries in BC. The first step, under what was known as the Mifflin Plan, was a $42 \%$ reduction in commercial salmon licenses, along with reduced access to fisheries through gear and area licensing changes (Fisheries and Oceans Canada 2002, Brown 2005). The rationale was economic efficiency; the consequence was a substantial transfer of assets, i.e., licenses, infrastructure, and population, from rural to urban British Columbia (Ecotrust 2004). With the Mifflin Plan under way at a cost to government of hundreds of millions of dollars (Fisheries and Oceans Canada 2002), the DFO adopted a policy known colloquially as weak stock management, under which fisheries are managed to protect weaker stocks at the expense of opportunities to harvest more productive stocks. Here, the rationale was a conservation crisis, in particular, an alarming decline in the numbers of coho salmon (Oncorhynchus kisutch) returning to spawn (Holtby and Finnegan 1997, Fisheries and Oceans Canada 1998a, Brown 2005).

Responding in part to increasing pressure from environmental and recreational groups, which have at times allied themselves with inland First Nations, the department has continued to reduce harvesting in favor of increasing spawner escapement throughout the Skeena system (Table 1). At the same time, there has been a transfer of access and withdrawal privileges to upriver recreational and aboriginal fisheries (Fisheries and Oceans Canada 1998-2012, Fisheries and Oceans Canada 1999, Walters et al. 2008). This reallocation of benefits from the fishery has taken place amidst a weakened consultation process. In 2005, the North Coast Advisory Board was replaced by a new body called the Integrated Harvest Planning Committee. Although more inclusive in its composition in that conservation interests have a formal place at the table, the Integrated Harvest Planning Committee has been criticized by participants as a highly politicized forum in which groups focus on positioning rather than cooperation and compromise. With the imminent implementation of the department's Wild Salmon Policy (Fisheries and Oceans Canada 2005) on the Skeena, the evidence points to an intensifying of weak stock management approaches and a continued shift of harvesting to terminal areas, where the different salmon stocks spawn at the end of their run.

The negative socioeconomic effects of the DFO's increasingly risk-averse fisheries management practices on the north coast have been felt most strongly in coastal communities, aboriginal and nonaboriginal, where dependence on commercial salmon fishing has long been the mainstay of local economies (Sinclair 1971, ARA Consulting Group 1996, Gislason et al. 1998, Jones et al. 2004). As a highly respected fisheries scientist pointed out in presentations to the DFO and commercial fishermen in the summer of 2012, the foregone harvests on Skeena sockeye stocks are worth millions of dollars to the fishing industry and the ecological benefits of weak stock management are very limited (C. J. Walters, unpublished Powerpoint presentation to the Area C harvesters and the Department of Fisheries and Oceans, Prince Rupert, British Columbia, Canada, July 2012). These unrealized landings mean less employment, less income, and less spending in coastal communities. This translates into fewer boats on the water, failing businesses, and decaying marine infrastructure. In turn, there is outmigration, especially among younger people entering the workforce, meaning fewer community leaders with 
Table 2. Sustainable Marine Fisheries and Communities Alliance's initial membership (2008) and subsequent participants (2008-2012; Thorkelson 2012, City of Prince Rupert 2013). See Figure 1 for locations of names in parentheses.

\begin{tabular}{lll}
\hline \hline Type & Name & Location \\
\hline First Nations & 2008: Gingolx, Gitga'at (Hartley Bay), Gitxaala (Kitkatla), Kitselas & North Coast, Nass River, Lower \\
& (Terrace), Kitsumkalum (Terrace), Lax Kw'alaams, Metlakatla, & Skeena River, Haida Gwaii, Central \\
& Nisga'a Lisims. Later: Council of Haida Nation, Heiltsuk (Bella & Coast \\
& Bella), Old Massett, Skidegate, Wuikinuxv (River's Inlet) & \\
& 2008: City of Prince Rupert, Skeena Queen Charlotte Regional & North Coast and Haida Gwaii \\
Local Governments & District, District of Port Edward & North Coast \\
& 2008: Native Brotherhood of BC, Northern Native Fishing & \\
Organizations & Corporation, United Fishermen and Allied Workers Union, North & \\
& Coast Skeena First Nations Stewardship Society & \\
\hline
\end{tabular}

decades of experience in the marine environment to make a case for the importance of protecting the ecosystem.

At least three negative feedback loops can be seen at work here, nested at different scales. First, loss of fishing opportunity diminishes the influence of commercial fishermen in the management system, which leads to further reductions in access. At a broader scale, the reduced economic, cultural, and social benefits flowing to communities from commercial fishing weakens popular interest in and support for the industry as a vital activity in the region, further undermining the institutions and actions that maintain the flow of benefits from fishing. Finally, at the scale of social-ecological interactions, the gap left by the decline of commercial fishing leaves the region vulnerable to arguments in favor of anything that will produce jobs, whatever the risk to marine and terrestrial ecosystems, which in turn reduces the value of the environment as a productive resource. For example, case study 2 shows the denial by government that salmon farms pollute clam beaches. That this third stage has not yet come to pass is arguably because of the continued importance of fishing on the north coast, however diminished it is now compared with 20 years ago. However, as the experience in Newfoundland demonstrates, coastal communities can make a radical shift from a capture fishing-centered suite of livelihoods to an oil and gas or aquaculture economy in little more than a generation (Bavington 2010, Sinclair 2012).

\section{Vision, strategies, and actions: counterbalancing the DFO through alliance building}

When the shift to increasing spawning escapement was getting under way in the mid to late 1990s, there were attempts by governments and stakeholders to create local management institutions that could help to resolve allocation issues (Skeena Watershed Committee 1996, Pinkerton 1996, 2009, Fisheries and Oceans Canada 1998b). Since the collapse of these initiatives after just a few years, partly through recreational sector lobbying becoming more powerful, the DFO has increasingly favored market mechanisms such as catch shares as a solution to many of the management issues it faces on the north coast (Schwindt et al. 2003, Butler 2008, Fisheries and Oceans Canada 2008, 2009, 2012).

In 2008, a coalition of north and central coast First Nations' governments, municipal governments, and commercial fishermen's organizations formed the Sustainable Marine Fisheries and Communities Alliance, hereafter the north coast group, in a bid to counterbalance those trends through lobbying, collaborative research, proposals, and initiatives to comanage or take over selected fisheries management functions. The initial membership of the alliance, dating from a series of meetings in May and June 2008, drew on communities and organizations close to or based in Prince Rupert. Since then, the organization has extended its membership to include communities in the Haida Gwaii archipelago and First Nations on the central coast as far south as Cape Caution (Table 2 and Fig. 1).

Fig. 1. Coastal British Columbia areas represented by Sustainable Marine Fisheries and Communities Alliance (A) and Musgamagw Dzawada'enuxw Tribal Council (B).

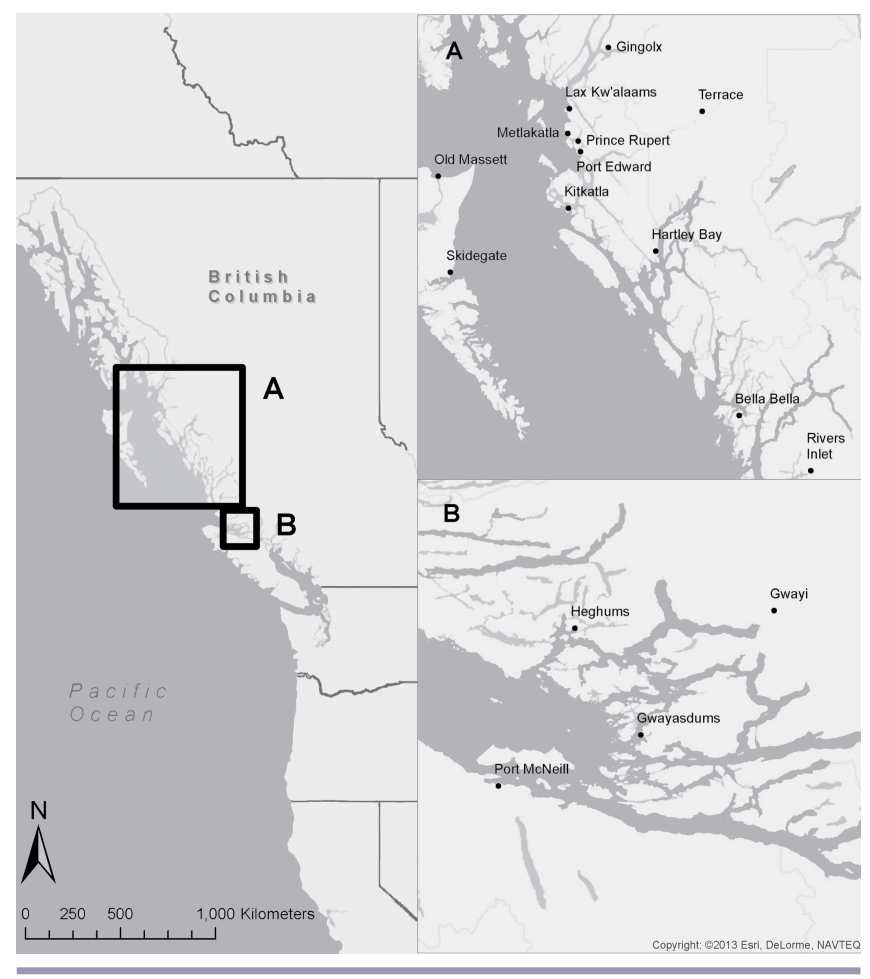

The following discussion considers the extent to which the activities of the north coast group constitute aspiring comanager behavior, as opposed to interest group lobbying in a landscape crowded with the latter. Primary data were collected through informal interviews and conversations with participants in the organization and through observation of several meetings, over 
Table 3. Fisheries management functions and Sustainable Marine Fisheries and Communities Alliance (SMFCA) goals and activities, 2008-2012 (Government of British Columbia 2010, Fernandes 2011, Thorkelson 2012, City of Prince Rupert 2013; SMFCA 2010, personal communication, unpublished documents). "Yes" in table below indicates that SMFCA is engaged in a particular activity.

\begin{tabular}{|c|c|c|c|c|c|}
\hline \multirow[t]{2}{*}{ Primary function } & \multirow[t]{2}{*}{ Subfunction } & \multicolumn{3}{|c|}{ Comanaging } & \multirow[t]{2}{*}{ Lobbying } \\
\hline & & Planning & Building & Doing & \\
\hline \multirow[t]{7}{*}{ Policy making and evaluation } & Scoping problems & Yes & & & Yes \\
\hline & Setting objectives & Yes & & & \\
\hline & Conducting research & Yes & & Yes & \\
\hline & Consulting user and interest groups & Yes & & & \\
\hline & Making policies & Yes & & & \\
\hline & Long range planning & Yes & & Yes & \\
\hline & Evaluating policies & Yes & & & \\
\hline \multirow[t]{6}{*}{ Conservation \& Productivity } & Habitat monitoring & Yes & Yes & & \\
\hline & Habitat protection & Yes & & & \\
\hline & Habitat restoration & Yes & & & \\
\hline & Habitat enhancement & & & & Yes \\
\hline & Stock assessment & & Yes & & Yes \\
\hline & Stock enhancement & Yes & & & Yes \\
\hline \multirow[t]{3}{*}{ Managing access } & Allocation & Yes & Yes & & Yes \\
\hline & Licensing & Yes & & & Yes \\
\hline & Membership transfers & Yes & & & Yes \\
\hline \multirow[t]{4}{*}{ Harvest management } & Planning & Yes & & & Yes \\
\hline & In-season management & Yes & Yes & Yes & Yes \\
\hline & Monitoring & Yes & Yes & Yes & \\
\hline & Enforcement & Yes & Yes & & \\
\hline \multirow[t]{3}{*}{ Adding value } & Supply management & Yes & & & \\
\hline & Traceability \& certification & Yes & Yes & & \\
\hline & Product diversification & Yes & & & Yes \\
\hline Resource use coordination & $\begin{array}{l}\text { Planning involving multiple fisheries } \\
\text { Ecosystem management }\end{array}$ & Yes & Yes & & \\
\hline \multirow[t]{2}{*}{ Communications \& Education } & Consensus building & Yes & Yes & Yes & \\
\hline & Public education & & & & \\
\hline \multirow[t]{3}{*}{ Human resources } & Retain fishermen & Yes & & & Yes \\
\hline & Upgrade skills & Yes & & & \\
\hline & Train new entrants & Yes & & & \\
\hline
\end{tabular}

the course of five research trips to Prince Rupert and the surrounding region from 2010 to 2013 . Field notes were combined with written documentation from secondary sources.

Table 3 conceptualizes a two-level hierarchy of fisheries management functions, all of which are amenable to comanagement in theory and for which comanagement has been observed in practice (Schlager and Ostrom 1993, Pinkerton and Weinstein 1995). Mapped onto the classification scheme are four columns categorizing the north coast group's activities according to whether or not they relate to comanaging at the stage of planning, building capacity, implementing ("doing" in Table 3), or lobbying. What is most striking is the gap between planning and doing: the members of the north coast group envision taking on a comanagement role in 26 of 30 aspects of salmon fisheries management, but the ability to do so to date has been limited to 5 aspects.

The most obvious explanation for the discrepancy between aspirations, or planning, and immediate accomplishments, or doing, is the complexity of what the coalition is trying to accomplish. Meeting in full once or twice a year since 2008, participants spend much time simply building agreement on contentious issues. Divisions stretching back decades or more among aboriginal groups and between the UFAWU and the Native Brotherhood of $\mathrm{BC}$ are a challenging legacy to overcome.
A closer look (Table 4) at the priority goals identified by the north coast group and the strategies the organization and its membership have used to build capacity and implement plans reveals substantial barriers to progress: limited resources, lack of trust between the marine commercial fisheries sector and upriver recreational and aboriginal fisheries, loss of capacity in government, and conflicts with government priorities.

Finally, the continued emphasis on lobbying shown in Table 3, especially in relation to access and harvest management functions in the fishery, suggests that the barriers to progress are substantial enough that recourse to lobbying is at this stage unavoidable, however ambitious the vision of cultural and institutional change may be. This should come as no surprise because the north coast group is still in the early stages of a long-term strategic plan to rebuild fisheries management institutions. The great strength of the group is that the membership knows what a successful fishery used to look like. Their challenge, as one participant expressed it, is to rebuild what they had with a different and better system.

\section{CASE STUDY 2: ABORIGINAL PEOPLE IN THE BROUGHTON ARCHIPELAGO}

Institutional losses in the Broughton clam fishery

Traditionally, Kwakwaka'wakw people used a complex system of de facto protocols to govern natural resources such as clams, 
Table 4. Sustainable Marine Fisheries and Communities Alliance (SMFCA) priority goals, strategies, and barriers (Thorkelson 2012, City of Prince Rupert 2013; SMFCA 2010, personal communication, unpublished documents). DFO= Canadian Department of Fisheries and Oceans.

\begin{tabular}{|c|c|c|}
\hline Priority Goals & Strategies & Barriers \\
\hline $\begin{array}{l}\text { Protect the resource and increase } \\
\text { productivity }\end{array}$ & $\begin{array}{l}\text { Improve habitat monitoring, protection and } \\
\text { restoration } \\
\text { Implement Alaska style ocean ranching }\end{array}$ & $\begin{array}{l}\text { Weakened legislative protection; government cutbacks; } \\
\text { SMFCA members' lack of resources } \\
\text { DFO refusal to discuss; lack of resources to develop } \\
\text { proposal }\end{array}$ \\
\hline $\begin{array}{l}\text { Negotiate new and lasting allocation } \\
\text { arrangements }\end{array}$ & $\begin{array}{l}\text { Make agreement with sports groups \& take to } \\
\text { government together } \\
\text { Make agreement with inland First Nations and } \\
\text { take to government together }\end{array}$ & $\begin{array}{l}\text { Mutual antagonism and lack of trust; limited incentives } \\
\text { to cooperate } \\
\text { Lack of trust; historical grievances }\end{array}$ \\
\hline $\begin{array}{l}\text { Expand aboriginal role in } \\
\text { monitoring, compliance, traceability, } \\
\text { harvest management } \\
\text { Improve socioeconomics for } \\
\text { fishermen and fishing communities }\end{array}$ & $\begin{array}{l}\text { Pursue partnerships with NGO's to develop } \\
\text { capacity through training and small-scale } \\
\text { management initiatives } \\
\text { Help drive research that can influence harvest } \\
\text { management decision rules and policy making }\end{array}$ & $\begin{array}{l}\text { Capacity limitations with SMFCA membership, } \\
\text { especially financial in short term (costly and difficult } \\
\text { DFO certification requirements) } \\
\text { DFO commitment to weak stock management; lack of } \\
\text { DFO capacity to understand and incorporate socio- } \\
\text { economic research in planning }\end{array}$ \\
\hline
\end{tabular}

primarily Butter, Saxidomus gigantea, and Littleneck, Leukoma staminea, clams, and clam gardens. Protocols are what Schlager and Ostrom (1993) call rules governing the operational-level, i.e., accessing and withdrawing, and collective-choice, i.e., management and exclusion, rights to common-pool resources. For instance, Rohner (1967:61) documents that in the eulachon fishery, "certain tribes had fishery rights at specific locations but not at others." Kwakwaka'wakw people interviewed by Heaslip (2008a) identified protocols related to access, management, exclusion, and stewardship of beaches and clam populations. For example, a protocol might require a clam digger to ask permission of a beach owner before digging on a particular beach and incur some responsibilities to the owner as to how the harvest was conducted. Our research team is currently working to document and compile a comprehensive list of clam fishery protocols in the Broughton Archipelago.

Historically, the Musgamagw Dzawada'enuxw (hereafter the Broughton clam group) and other Kwakwaka'wakw First Nations governed the use of an abundance of marine resources, including several species of Pacific salmon, herring, eulachons, halibut and other groundfish, seals, sea lions, sea otters, porpoises, kelp, clams, mussels, crabs, and other shellfish (Codere 1950). The Broughton Archipelago has always been the breadbasket of the Broughton clam group. Clam gardens are a form of traditional mariculture developed by Kwakwaka'wakw and other First Nations on the BC coast to manage clam populations (Williams 2006). Empirical and experimental evidence has shown that clam gardens likely increased clam productivity (Groesbeck 2013). Evidence of their significance as a traditional management practice for Kwakwaka'wakw people inhabiting the Broughton Archipelago can be seen by the fact that 350 of these clam "terrace" locations have been documented along 5\%-10\% of the region's rocky coastline (Harper et al. 1995).

Institutional knowledge and practice of traditional protocols have weakened as a result of interventions in marine resource management during the colonial and postcolonial eras. Since first European contact in 1792, Kwakwaka'wakw nations' communal management systems have been overwhelmed by their loss of regular access to a diversity of marine resources. By the early 1960 s, commercial fishing for salmon and intertidal clams served as the primary income source for 18 of the 24 men living in the clam group's village of Gwayasdums on Gilford Island; 8 of them owned gillnet boats (Rohner 1967). By 2012, the combination of fleet rationalization and other policies left only one person from Gwayasdums, who resides in Victoria, with a salmon license.

British Columbia saw a rapid influx of commercial harvesters entering the intertidal clam fishery during the 1980s, and by 1988 landings of all clam species had peaked (Fisheries and Oceans Canada 1998c). At this point, the accumulated stocks on most beaches along the province's coast had been removed and the DFO began implementing more restrictive management measures with reduced harvest times (Fisheries and Oceans Canada 1998c). We hypothesized that in areas such as the Broughton Archipelago, these high commercial landings of clams were only made possible by exploiting the clam abundance created through historical management of clam beaches by aboriginal people. Thus, the federal government's failure to understand the significance of traditional management practices in conserving clam stocks or to develop an appropriate alternative has resulted in a steady decline in stock abundance. Intertidal clams were the last fishery to be separately licensed as a limited entry fishery, in 1998 , and it is the only remaining fishery in which Broughton clam group members participate significantly.

In addition to fleet rationalization, the DFO's territorial boundaries for clam management ignored the tribes' traditional territorial boundaries for management based on protocols. This created challenges for exercising traditional management institutions, although politically skilled elders were able to compensate to some extent and for some time as protocols were initially adapted for the commercialized clam fishery.

The DFO's management approach continues to have drastic effects on the traditional clam management system. The sciencebased monitoring techniques used to inform the DFO's management decisions do not include traditional ecological knowledge of the health of the clam stocks, which differs from that of the DFO (Heaslip 2008b). Kwakwaka'wakw are 
Table 5. Broughton clam group members' identification of problems in clam management.

\begin{tabular}{|c|c|c|}
\hline Issues & Causes & Community Concerns \\
\hline \multirow{9}{*}{$\begin{array}{l}\text { Failures in } \\
\text { Habitat Protection and } \\
\text { Change }\end{array}$} & \multirow[t]{4}{*}{ Salmon aquaculture } & Beaches damaged by farmed salmon feces \\
\hline & & Blackening or discoloration of clams \\
\hline & & Declining beach quality - mucky, thicker, stinky \\
\hline & & Slower growth/die offs of clams near fish farms \\
\hline & \multirow[t]{2}{*}{ Sewage } & Harvest closures near village's sewage outfall \\
\hline & & Sewage waste from float houses \\
\hline & \multirow[t]{2}{*}{ Accidents releasing oil } & Oil leaks from boats \\
\hline & & Fear of potential oil spills \\
\hline & Greenhouse gases & Changes in seasons due to climate change \\
\hline \multirow{9}{*}{$\begin{array}{l}\text { Harvest Management } \\
\text { Failures }\end{array}$} & Overharvesting in commercial & Over-harvesting by diggers \\
\hline & fisheries & $\begin{array}{l}\text { Some diggers prioritize short-term income over long-term sustainability of the fishery } \\
\text { All fisheries in the region have declined due to overharvesting or re-allocation (salmon, } \\
\text { halibut) }\end{array}$ \\
\hline & $\begin{array}{l}\text { Breakdown in the observation } \\
\text { of traditional practices }\end{array}$ & $\begin{array}{l}\text { Neither aboriginal people nor outsiders any longer respect traditional land ownership } \\
\text { and protocols: not seeking permission to harvest }\end{array}$ \\
\hline & Monitoring and enforcement & Little monitoring by DFO or others \\
\hline & & Stock assessment by consulting firm includes data from beaches closed for \\
\hline & & $\begin{array}{l}\text { contamination, producing inaccurate representation of stocks accessible to the fishery } \\
\text { Harvesting on closed beaches and mislabeling beach information on clam sack tags }\end{array}$ \\
\hline & & $\begin{array}{l}\text { Harvesting on closed beacnes and mislabeling beach information on clam sack tags } \\
\text { Multiple diggers illegally using single license }\end{array}$ \\
\hline & & Undersized clams are being harvested \\
\hline & & Too many licenses are distributed \\
\hline
\end{tabular}

concerned that salmon aquaculture waste pollutes their clam beaches (Heaslip 2008b). In recent years, clam stock assessments have not been a federal priority, so the Broughton clam group lacks area wide clam stock status information. The DFO (Fisheries and Oceans Canada 2010) recognizes that illegal clam harvesting presents health, safety, and conservation concerns. In the Broughton Archipelago, illegal harvesting occurs largely because of unmonitored harvesting on closed contaminated beaches, unlicensed harvesters, and improper reporting, e.g., mislabeled clam sack tags.

Aboriginal capacity to monitor and enforce traditional management protocols, thus maintaining a sustainable clam fishery, was diminished by the loss of salmon fishing licenses and boats, which had given them access to the territory. In the absence of DFO capacity to monitor and enforce federal regulations, the four nations in the Broughton clam group, Dzawada'enuxw, Gwawa'enuxw, and two nations amalgamated into Kwickwasut'inuxw Haxwa'mis, are taking actions to reestablish past traditional management protocols, with the vision of implementing a management structure that meets their need to ensure the stewardship of these valuable shellfish areas.

\section{Vision, strategies, and actions: reasserting protocols}

The Broughton clam group asserts the need to have control over local natural resources and to protect the territory by exercising their traditional management protocols. Community leadership has indicated that while the clam fishery generates a comparatively small amount of revenue versus other fisheries, it remains critical to the survival of the communities as their last remaining commercial fishery. The majority of the more than 200 clam beaches in DFO-designated Clam Area G fall within the traditional territories of the four clam group nations, which together are administered by the Musgamagw Dzawada'enuxw Tribal Council. Cumulatively, these four nations have more than
800 registered members, approximately half of whom live outside the community, often because of lack of housing and jobs. Their three inhabited villages, Gwayasdums, Gwayi, and Heghums, are connected to regional urban centers only by sea or air.

Since 2001, the Broughton clam group has been working alongside other Kwakwaka'wakw nations in requesting increased formal rights through a proposed clam board comanaged with the DFO (Pacific Regional Clam Management Committee 2001). However, in recent years DFO representatives have wavered in their support for such a board, at one point seeking to temporarily take the idea off the table by stating that they were supportive but "sources of DFO funding support for such boards was very limited and not identified for the Area G fishery at this time" (Pacific Regional Clam Management Committee 2007:3). Although the DFO has granted the majority of clam fishery access and withdrawal rights to aboriginal people in the Broughton Archipelago and are continuing to discuss a possible consultative clam management board, they have not yet recognized the legitimacy and effectiveness that local management has in sustaining the fisheries resource (Pinkerton and John 2008) and the importance of involving aboriginal communities in all stages of management decisions and practices (Turner et al. 2013), i.e., comanagement. Management does not operate in a contextual and historical vacuum. Successful comanagement actively seeks to learn from, adapt to, and reincorporate local knowledge and traditional management protocols, which previously formed the basis of the demonstrably sustainable management of a First Nations' fishery that existed for thousands of years.

In Tables 5 and 6 we summarize (1) the Broughton clam group's identification of clam management problems and (2) their goals, perceived barriers, and proposed strategies to address these problems. We focused on the community historically known as 
Table 6. Priority goals, strategies, and barriers in implementing local clam management strategies as identified by Broughton clam group members. DFO = Canadian Department of Fisheries and Oceans.

\begin{tabular}{|c|c|c|}
\hline Priority Goals & Proposed Strategies for the tribal council & Barriers \\
\hline Reinstating protocols & $\begin{array}{l}\text { Hire a cultural advisor/ Teach youth about protocols } \\
\text { Gather in cultural centers (big houses) to discuss the } \\
\text { protocols }\end{array}$ & $\begin{array}{l}\text { Recognition of staffing constraints within tribal } \\
\text { council } \\
\text { Short-term funding requirements }\end{array}$ \\
\hline Increase communication & $\begin{array}{l}\text { Within the clam group nations } \\
\text { With other aboriginal and nonaboriginal fishers } \\
\text { With government (DFO) } \\
\text { Require clam diggers communicate with the clam group } \\
\text { about digging in the territory }\end{array}$ & $\begin{array}{l}\text { Recognition of staffing constraints within tribal } \\
\text { council } \\
\text { Grievances with other aboriginal and } \\
\text { nonaboriginal fishers } \\
\text { Lack of DFO staffing capacity and commitment } \\
\text { to meet more regularly }\end{array}$ \\
\hline $\begin{array}{l}\text { Increase capacity to monitor and } \\
\text { enforce local management }\end{array}$ & $\begin{array}{l}\text { Seek funding } \\
\text { Hire and train fisheries guardians and biologists } \\
\text { Purchase a boat for fisheries guardians } \\
\text { Map clam beaches }\end{array}$ & Uncertainty of short-term funding opportunities \\
\hline $\begin{array}{l}\text { Collaborate with DFO on a new } \\
\text { management strategy }\end{array}$ & $\begin{array}{l}\text { Work to ensure management plans reflect community } \\
\text { values and interests }\end{array}$ & $\begin{array}{l}\text { Lack of consensus between DFO and } \\
\text { Kwakwaka'wakw nations } \\
\text { DFO's use of standardized clam management } \\
\text { board framework }\end{array}$ \\
\hline
\end{tabular}

the clam capital of the area (Rohner 1967), Gwayasdums, where Percy Williams and Neil Ladell conducted interviews with 14 Kwickwasut'inuxw Haxwa'mis Broughton clam group members during five weeks of residence there in June and July 2012. Interviewees included elected councilors, an elder, active and retired clam harvesters, and other community members. The information provided in these tables underscores community members' perceptions that reinstating protocols is critical for overcoming current failures in clam management.

\section{DISCUSSION}

The north coast and Broughton clam group cases exemplify efforts to build or rebuild comanagement institutional arrangements at different geographic scales, membership scales, and degrees of membership diversity, across a varying breadth of issues, diverse types of rights being asserted, complexities of species mix, and stages of development. Although in many ways the two case studies are not comparable, their participants do face some of the same institutional losses and barriers to rebuilding; they also experience some of the same conditions that have been identified as leading to comanagement success. Because the north coast group is much larger in geographic and membership scale and because it benefits from long-established leadership and resources from two historically powerful province-wide fishing organizations (UFAWU and the Native Brotherhood of BC), it exhibits strength in some areas that is absent in the Broughton clam group. On the other hand, the Broughton clam group operates in a more homogeneous environment and with fewer species, so it exhibits strength through its cultural cohesiveness and its strong agreement on issue definition and priorities. Table 7 summarizes the institutional losses, as well as visions, strategies, and actions being taken to rebuild institutions, in the two cases.

The comanagement and self-management literature about the most critical conditions for successful local institutional rebuilding identifies the following conditions for successful comanagement, each of which appears relevant to one or the other of the two cases. These are summarized in Tables 8 and 9 as resources held and actions taken.

\section{Conditions in communities and regions}

1. Existence of strong identification with place. Communities of place have the greatest likelihood of being willing to monitor poaching, overharvesting, and pollution and to protect places from these things over the long term. In many aboriginal communities, moral teachings about proper behavior are encoded in local landscapes (Basso 1996) or are part of spiritual beliefs about the natural word, developed over time and transmitted through myth, ritual, and an intensely personal and emotional worldview that encapsulates critical information about long-term survival in local landscapes and ecosystems (Anderson 1996, Berkes 1999, Atleo 2011). Such attachment to place constitutes an invaluable asset when it can be linked to local rule making about sustainable fishing practices (Pinkerton and John 2008, Lepofsky 2009, Caldwell et al. 2012).

2. Existence of strong local community values that influence perceptions and actions. As an extension of condition 1, aboriginal beliefs are logical components of worldviews that are often powerful mechanisms for conservation because they inculcate values that promote individual restraint rather than solely rational calculations of material gain. To the community, the purpose of management is the sustainable and reliable provision of community food and material needs. Langdon (2007) illustrates how such values are based on a mythic charter, or contract between fishing communities and the species, which are believed to remain abundant only if treated according to values of sustainable use, e.g., not wasting or taking more than needed. Nonaboriginal communities likewise can have both strong identification with place and also community values that lead them to manage sustainably, usually through local rule making (Acheson 1975, Ostrom 1990).

3. Existence of a cohesive social system based on kinship, ethnicity, or homogeneous gear. Commonly held values about how to fish can emerge either from family or social group ties or from being part of an organization representing the 
Table 7. Original institutional loss, visions, strategies, and actions to rebuild institutions.

\begin{tabular}{|c|c|c|}
\hline & Broughton clam group & North coast group \\
\hline $\begin{array}{l}\text { Institutional losses, } \\
\text { vacuums, and } \\
\text { vulnerabilities }\end{array}$ & $\begin{array}{l}\text { Minimal community representation in management process } \\
\text { Declining observation of traditional management practices } \\
\text { Loss of access to resources } \\
\text { Loss of abundance of resource } \\
\text { Loss of health of resource } \\
\text { Loss of capacity and transportation }\end{array}$ & $\begin{array}{l}\text { Loss of mechanism for community representation in } \\
\text { management process (vacuum), loss of influence, loss of } \\
\text { capacity }\end{array}$ \\
\hline Vision & $\begin{array}{l}\text { Take back control over local natural resources, be able to } \\
\text { protect territory and exercise traditional protocols }\end{array}$ & Make policies for region that benefit communities \\
\hline Strategies & Document and formalize traditional protocols & $\begin{array}{l}\text { Increase salmon abundance; ensure fair allocation; } \\
\text { aboriginal comanagement }\end{array}$ \\
\hline Actions & $\begin{array}{l}\text { Engage in research partnership with universities } \\
\text { Maintain planning focus on core values and interests }\end{array}$ & $\begin{array}{l}\text { Planning, research, monitoring, some harvest management; } \\
\text { research partnerships }\end{array}$ \\
\hline
\end{tabular}

interests and concerns of a particular type of fisherman such as a salmon gillnetter. The cohesiveness of the group lends strength to the values, norms, and rules it produces (Pinkerton 1989).

4. Existence of mechanisms for conserving and enhancing a fishery that can at the same time conserve and enhance the operation of a cultural system (Pinkerton 1989). As exemplified especially by the Broughton clam group, rebuilding the traditional cultural system of access and management protocols would automatically produce the sustainable management and best practices that the system was originally designed to achieve.

5. Existence of legitimate and effective leadership at local and regional levels, i.e., a dedicated person or core group applying consistent pressure to advance the process (Pinkerton 1989). Leadership in fisheries management from both the UFAWU-UNIFOR and the Native Brotherhood of BC is particularly strong in the north coast group, especially in the form of an energy center with four decades of experience dedicated to pursuing the goals. Leadership at multiple scales is important and may not be consistently present at local scales. The existence of such fisheries leadership is only now beginning to emerge in the Broughton Archipelago.

6. Achievement of local consensus on the importance of management protocols and traditional territorial rights. This produces the type of multiparty agreements that Poncelet (2001) and Pinkerton (2007) identified as playing an inherently powerful role in influencing government policy decisions. This goal appears achievable within the Broughton clam group and also among participants in the north coast group. The challenge will be to persuade the other claimants to the salmon and clams to recognize and respect what the clam group's management protocols and the north coast group's approaches have to contribute to sustainable management.

7. Exertion of management rights in addition to or even instead of access rights. The north coast member organizations have always exerted access rights and are only recently exerting a wide range of management rights. The Broughton clam group is in the fairly unusual position of currently taking the moral high ground, exerting only management rights, that is, protecting the beaches and practicing protocols, separately from and not directly tied to access rights. This may help them in asserting the moral legitimacy of their claim.

8. Ability to articulate a coherent and consistent vision that can be clearly translated to government and the public (Pinkerton 1993). The ability of these coalitions to persuade other claimants to recognize the legitimacy of the coalitions will be influenced by their ability to clearly explain the value of their vision to government and the local public. In the process, they may be able to build issue networks with government scientists and managers, showing how their coalition can solve specific problems.

9. Ability to form issue networks. Heclo (1978) identifies issue networks as a major source of reform pressure for governmental processes that have previously been dominated by a few economic players. Issue networks are formed when experienced government personnel, public sector leaders, academics, independent consultants, and nonaligned scientists familiar with research, technical information, and alternative working models generate a free and lively debate about policy and technical alternatives. The ability of an issue network to combine such diverse resources effectively allows it both to produce and legitimize workable models. The DFO and the north coast group appear to be developing an issue network to a moderate degree, but it is too early for this to happen with the Broughton clam group.

10. Ability to form coalitions at the local, regional, provincial, national, and international levels. Coalition formation is happening at different scales in the two regions. Because both the UFAWU-UNIFOR and the Native Brotherhood of $\mathrm{BC}$ are province-wide organizations, they are able to form coalitions on the $\mathrm{BC}$ north coast and enjoy moral support provincially. As part of the Canadian Council of Professional Fish Harvesters, the UFAWU-UNIFOR and the Native Brotherhood of BC participate in a national coalition, and our partnership research is part of a national research network: the Canadian Fisheries Research Network. The Broughton clam group is just beginning to be part of an international research network on small-scale fisheries called Too Big to Ignore. Both research projects are documenting the value and role of such fisheries in coastal communities, regional economies, and nation states. 
Table 8. Resources that support rebuilding local fisheries management institutions: assessment and comparison of north coast and clam groups. DFO = Canadian Department of Fisheries and Oceans.

\begin{tabular}{lcc}
\hline \hline Resource & North coast group & Clam group \\
\hline Identification with place & Strong (Doing) & Strong (Doing) \\
Influential local community values & Strong (Doing) & Strong (Doing) \\
Cohesive social system & Building & Strong (Doing) \\
Legitimate and effective leadership in fisheries management & Strong & Building \\
Historical experience and success with comanagement institutions & Building & Planning \\
with DFO & & Planning \\
Capacity for political mobilization around fisheries issues & Strong (Doing) & Planning \\
External support & Building & Planning \\
Access to financial, logistical, and technical resources & Building & Planning \\
Institutional capacity in senior governments (staffing, budgets, & Diminishing & Planning \\
function) & Building & Building \\
Government representatives trained to work with fishermen and & Strong \\
Statutory, regulatory, or policy support for local interests and values & Building & Strong \\
Motivating crisis & &
\end{tabular}

11. Ability to demonstrate that radical reform is necessary and not being addressed (Pinkerton 1992). The north coast group is demonstrating this to its own membership but not yet to outsiders. The Broughton clam group is raising the issue of salmon farm pollution of clam beaches through its environmental and other aboriginal allies, which may position it to raise other issues.

12. Capacity for political mobilization. Submissions to the hearings of the Joint Review Panel on the proposed Enbridge Northern Gateway pipeline and associated tanker transportation to China for Alberta bitumen illustrated the capacity of the north coast group to mobilize local protest around habitat protection issues. The Broughton clam group is not at this stage yet, but may become involved with the Coastal Guardian Watchmen for training and development of monitoring capacity.

13. Access to public forums of debate and dissemination of opinion. The north coast group has access to local newspaper and radio forums on the north coast and uses them to a limited extent, but has not yet entered into debate in the public arena. The Broughton clam group uses social media for internal debate among member nations only. A recent challenge by a neighboring aboriginal nation over territorial ownership rights appears to be stimulating greater use of public forums, however, and this may be beneficial in the long run for the public discussion of management protocols.

14. Access to financial and logistical resources, such as volunteerism and political will, that enable a community or region to organize itself effectively. Both organizations are financially pressed and surviving through political will and significant volunteerism, especially the north coast group.

15. Capacity to do asset mapping. Asset mapping combines all sources of physical, human, social, and cultural capital. The extensive assets held by both organizations, such as placebased knowledge of ecosystems, closely knit kinship networks, past sustainable management skills, and so forth, offer key assets for effective local management. A thorough appreciation of those assets is helpful in creating the priorities that allow an organization to play to its strengths (Kretzmann and McKnight 1993). Both organizations appear to have this appreciation.

\section{External political conditions}

1. Existence of a crisis pushing people to take action and overcome local differences (Pinkerton 1989). In both organizations there is a sense of urgency that it is now or never. If they do not take immediate action, the opportunity to rebuild their institutions will be lost. This situation is positive in that external threats can provide a powerful motivation for local factions to unite to protect their mutually held values and interests.

2. Existence of external support. Examples include university researchers, nongovernment scientists, credible organizations, and external forums of discussion such as issue networks.

3. Alliances with stakeholders, nongovernmental organizations, and agencies with complementary resources, especially when these parties form issue networks that generate new technical information and alternative models. An environmental nongovernmental organization, Ecotrust, is supportive of the north coast group, and a prominent independent scientist, Alexandra Morton, is supportive of the clam group. The clam group is in the process of setting up a meeting with stakeholders in their area to explore common concerns and mutual support.

4. Access to and use of multiple sources of power. These sources, including courts, legislatures, public boards, and citizens' initiatives at strategic times, create a spillover effect from one to another. The western Washington treaty tribes were particularly successful in asserting a high level of comanagement rights through access to multiple forms of power (Pinkerton 1992). It is not clear to us that either organization currently has such access.

\section{Conditions in government agencies}

1. Loss of institutional capacity in government resulting from job cuts and reorganization. This leads to less ability of 
Table 9. Activities that support rebuilding local fisheries management institutions: assessment and comparison of Skeena and Broughton regions.

\begin{tabular}{|c|c|c|}
\hline Activity & $\begin{array}{l}\text { North coast } \\
\text { group }\end{array}$ & Broughton Clam group \\
\hline Building coalitions at local and regional levels & Doing & Planning on some issues \\
\hline $\begin{array}{l}\text { Forming alliances with stakeholders, NGOs and agencies with } \\
\text { complementary resources }\end{array}$ & Building & $\begin{array}{l}\text { Building on habitat protection; Planning on } \\
\text { other issues }\end{array}$ \\
\hline Creating issue networks with government and academic experts & Building & Building \\
\hline Accessing media and public space & Doing & Planning \\
\hline Accessing multiple sources of power & Building & Building \\
\hline $\begin{array}{l}\text { Identifying and fostering positive feedback loops between ecological and } \\
\text { social systems (how cultural system can support institutional rebuilding) }\end{array}$ & Planning & Doing \\
\hline Articulating coherent and consistent vision for government and public & Building & Building \\
\hline Demonstrating necessity for radical reform and absence of progress & Building & Planning \\
\hline Exerting management rights over and above access rights & Building & Building de facto, planning de jure \\
\hline
\end{tabular}

government to deal with policy or operational decisions affecting local management. Although a deficit in the short term, this condition may be a blessing in the long term in that it can mobilize local communities to step into the breach. The lack of DFO funding to start a Clam Board in the Broughton Archipelago is a barrier for the clam group but could allow them to take a leadership role regarding regional issues. The north coast group may be able to play a larger management role because of DFO absence from its previous management activities.

2. Lack of training of government managers to work with fishermen or communities, despite policies to do so. This lack of training results in the low likelihood that community values or capacity to participate in management will be understood or incorporated into management decisions (Sharp and Lach 2003). This condition exists most strongly in the Broughton area, although it is not absent in the Skeena.

3. Government's behavioral bias toward the fragmentation of responsibilities and authorities (Yaffee 1997, Pinkerton 2007). This inhibits the development of the integrated comanagement process that is sought by both organizations.

\section{CONCLUSIONS}

Tables 8 and 9 summarize the resources available to the north coast and Broughton clam groups, and the activities each organization is undertaking to achieve its goals in rebuilding its own collapsed institutions or in rebuilding comanagement institutions ("doing" in Tables 8 and 9). Both organizations face the dilemma of deciding whether to focus limited time and resources on acquiring or mobilizing more of the resources they need or to take more actions that are likely to advance their objectives. Both organizations probably have sufficient favorable conditions to achieve their goals but would likely benefit from asset mapping to make difficult decisions about the trade-offs. Although both organizations need financial resources, their need for external support in the form of alliances, issue networks, and sources of power is far greater and finances do not automatically deliver these. Much of the comanagement literature suggests that this strategy can significantly enhance the successful assertion of comanagement rights that enable institutional rebuilding.
Responses to this article can be read online at: http://www.ecologyandsociety.org/issues/responses. $\mathrm{php} / 6489$

\section{Acknowledgments:}

We thank the Social Sciences and Humanities Research Council of Canada for their contribution through a Partnership Development Grant to Evelyn Pinkerton and the Musgamagw Dzawada'enuxw Tribal Council (among others). We also thank the Natural Sciences and Engineering Council of Canada for their contribution through a grant to principal investigator Robert Stephenson, and coapplicants Evelyn Pinkerton and the United Fishermen and Allied Workers Union-UNIFOR. We are grateful to Barbara Neis for organizing such an inspiring Symposium on Rebuilding Collapsed Fisheries.

\section{LITERATURE CITED}

Acheson, J. M. 1975. The lobster fiefs: economic and ecological effects of territoriality in the Maine lobster industry. Human Ecology 3:183-207.

Ahousaht et al. vs. Canada (Attorney General). 2013. Ahousaht et al. vs. Canada (Attorney General). British Columbia Court of Appeal 300, Vancouver, British Columbia, Canada.

Ahousaht First Nation vs. Canada (Fisheries and Oceans). 2007. Ahousaht First Nation vs. Canada (Fisheries and Oceans). Docket number T-781-06. Federal Court 567, Vancouver, British Columbia, Canada.

Anderson, E. N. 1996. Ecologies of the heart: emotion, belief, and the environment. Oxford University Press, Oxford, U.K.

Angel, E. 2011. Potential impacts of the Enbridge Northern Gateway pipeline project on commercial fishing and fishing communities on BC's north coast. Report prepared for the United Fishermen and Allied Workers' Union. 21 December. United Fishermen and Allied Workers' Union, Prince Rupert, British Columbia, Canada. [online] URL: https://docs.neb-one.gc.ca/lleng/llisapi.dll/fetch/2000/90464/90552/384192/620327/624910/697824/783165/D203-5-3 - United_Fishermen and_Allied_Work- 
ers Union-CAW - UFAWU-CAW Angel Socio Economic report A2L1K6.pdf?nodeid $=783048 \&$ vernum $=-2$

ARA Consulting Group. 1996. Fishing for answers: coastal communities and the BC salmon fishery: final report. Contributors: G. S. Gislason, E. Lam, M. Mohan, and the British Columbia Job Protection Commission. Ministry of Agriculture, Fisheries and Food, Victoria, British Columbia, Canada.

Armitage, D., F. Berkes, and N. Doubleday, editors. 2007. Adaptive co-management: collaborative learning and multi-level governance. University of British Columbia Press, Vancouver, British Columbia, Canada.

Atleo, E. R. 2011. Principles of Tsawalk: an indigenous approach to global crisis. University of British Columbia Press, Vancouver, British Columbia, Canada.

Barman, J. 1991. The West beyond the West: a history of British Columbia. University of Toronto Press, Toronto, Ontario, Canada.

Basso, K. H. 1996. Wisdom sits in places: landscape and language among the Western Apache. University of New Mexico Press, Albuquerque, New Mexico, USA.

Bavington, D. 2010. Managed annihilation: an unnatural history of the Newfoundland cod collapse. University of British Columbia Press, Vancouver, British Columbia, Canada.

Berkes, F. 1981. The role of self-regulation in living resources management in the North. Pages 166-178 in M. M. R. Freeman, editor. Renewable resources and the economy of the North. Association of Canadian Universities for Northern Studies/MAB, Ottawa, Ontario, Canada.

Berkes, F. 1999. Sacred ecology: traditional ecological knowledge and resource management. Taylor and Francis, New York, New York, USA.

Brown, D. 2005. Salmon wars: the battle for the West Coast salmon fishery. Harbour, Madeira Park, British Columbia, Canada.

Butler, C. F. 2008. Paper fish: the transformation of the salmon fisheries of British Columbia. American Fisheries Society Symposium 68:75-98.

Caldwell, M. E., D. Lepofsky, G. Combes, M. Washington, J. R. Welch, and J. R. Harper. 2012. A bird's eye view of northern coast Salish intertidal resource management features, southern British Columbia, Canada. Journal of Island and Coastal Archeology 7 (2):219-233. http://dx.doi.org/10.1080/15564894.2011.586089

Campbell, D., C. P. Burgess, S. T. Garnett, and J. Wakeman. 2011. Potential primary health care savings for chronic disease care associated with Australian Aboriginal involvement in land management. Health Policy 99(1):83-89. http://dx.doi.org/10.1016/ j.healthpol.2010.07.009

Chandler, M. J., and C. E. Lalonde. 2009. Cultural continuity as a moderator of suicide risk among Canada's First Nations. Pages 221-248 in L. J. Kirmayer and G. G. Valaskakis, editors. Healing traditions: the mental health of Aboriginal peoples in Canada. University of British Columbia Press, Vancouver, British Columbia, Canada.

City of Prince Rupert. 2008. Archived info to Council. 14 November. Prince Rupert, British Columbia, Canada.
City of Prince Rupert. 2010a. Archived info to Council. 13 January. Prince Rupert, British Columbia, Canada.

City of Prince Rupert. 2010b. Archived info to Council. 17 November. Prince Rupert, British Columbia, Canada.

City of Prince Rupert. 2011a. Archived info to Council. 13 April. Prince Rupert, British Columbia, Canada.

City of Prince Rupert. 2011b. Archived info to Council. 18 May. Prince Rupert, British Columbia, Canada.

City of Prince Rupert. 2011c. Archived info to Council. 22 June. Prince Rupert, British Columbia, Canada.

City of Prince Rupert. 2012. Archived info to Council. 9 May. Prince Rupert, British Columbia, Canada.

City of Prince Rupert. 2013. Archived info to Council. 14 November 2008, 13 January 2010, 17 November 2010, 13 April 2011, 18 May 2011, 22 June 2011, 9 May 2012. Prince Rupert, British Columbia, Canada.

Codere, H. 1950. Fighting with property. American Ethnological Society Monograph 18. JJ Augustine, New York, New York, USA.

Drucker, P. 1958. The native brotherhoods: modern intertribal organizations on the Northwest coast. Smithsonian Institution, Bureau of American Ethnology. Bulletin 168. United States Government Printing Office, Washington, D.C., USA.

Ecotrust. 2004. Catch-22. Conservation, communities, and the privatization of BC fisheries. An economic, social and ecological impact study. Ecotrust Canada, Vancouver, British Columbia, Canada. [online] URL: http://www.inforain.org/reports/

Catch 22 Full Report November2004.pdf

English, K. 2012. Extend the time-series of catch and escapement estimates for Skeena sockeye, pink, chum and coho salmon stocks. Skeena Salmon Program, Vancouver, British Columbia, Canada. [online] URL: http://skeenasalmonprogram.ca/libraryfiles/lib 262. pdf

English, K. K., C. Noble, and A. Blakley. 2012. Skeena sockeye in-river run reconstruction analysis model and preliminary analysis results for 1982-2009. Pacific Salmon Foundation, Vancouver, British Columbia, Canada.

Fernandes, D. 2011. An update from Ecotrust Canada's Skeena team. 17 November. Ecotrust Canada, Vancouver, British Columbia, Canada. [online] URL: http://ecotrust.ca/fisheries/anupdate-ecotrust-canada-skeena-team.

Fisheries and Oceans Canada. 1990. Pacific Coast commercial fishing licensing policy: discussion paper. Fisheries and Oceans Canada, Government of Canada, Ottawa, Canada.

Fisheries and Oceans Canada. 1998a. A new direction for Canada's Pacific salmon fisheries. Fisheries and Oceans Canada, Government of Canada, Ottawa, Canada. [online] URL: http:// www.dfo-mpo.gc.ca/Library/230220.pdf.

Fisheries and Oceans Canada. 1998b. Skeena-Kitimat sustainable fisheries program, final report, 1993-1997. Fisheries and Oceans Canada, Vancouver, British Columbia, Canada. 
Fisheries and Oceans Canada. 1998c. Pacific Region 1999 management plan: intertidal clams. Fisheries and Oceans Canada, Government of Canada, Ottawa, Canada.

Fisheries and Oceans Canada. 1998-2012. Integrated fisheries management plans, salmon, Northern BC. Fisheries and Oceans Canada, Government of Canada, Ottawa, Canada.

Fisheries and Oceans Canada. 1999. An allocation policy for Pacific salmon. A New Direction: the fourth in a series of papers from Fisheries and Oceans Canada. Fisheries and Oceans Canada, Government of Canada, Ottawa, Canada.

Fisheries and Oceans Canada. 2002. Evaluation of the Canadian fisheries adjustment and restructuring program license retirement programs evaluation report. Fisheries and Oceans Canada Review Directorate, Government of Canada, Ottawa, Canada.

Fisheries and Oceans Canada. 2005. Canada's policy for conservation of wild Pacific salmon. Fisheries and Oceans Canada, Vancouver, British Columbia, Canada.

Fisheries and Oceans Canada. 2008. Workshop summary: DFO internal workshop on implementing share based management in the Pacific Salmon Fishery. Cohen Commission Exhibit 471. Cohen Commission, Vancouver, British Columbia, Canada.

Fisheries and Oceans Canada. 2009. Discussion paper: towards share based management of the British Columbia commercial salmon fishery. Cohen Commission Exhibit 469. Cohen Commission, Vancouver, British Columbia, Canada.

Fisheries and Oceans Canada. 2010. Pacific region integrated fisheries management plan: intertidal clams (January 1, 2010 to December 31, 2012). Fisheries and Oceans Canada, Nanaimo, British Columbia, Canada. [online] URL: http://www.dfo-mpo. gc.ca/Library/338991.pdf.

Fisheries and Oceans Canada. 2012. The future of Canada's commercial fisheries: a discussion document. Fisheries and Oceans Canada, Government of Canada, Ottawa, Canada.

Gislason, G., E. Lam, and E. Battle. 1998. Fishing for direction: transition support for BC fishermen and their communities. Prepared for Fisheries and Oceans Canada. GSGislason \& Associates, Vancouver, British Columbia, Canada.

Government of British Columbia. 2010. Official reports of debates of the Legislative Assembly. 11 February (G. Coons, New Democratic Party). Victoria, British Columbia, Canada. [online] URL: http://www.leg.bc.ca/hansard/39th2nd/h00211p.htm

Groesbeck, A. S. 2013. Ancient clam gardens increased production: adaptive strategies from the past can inform food security today. Thesis. School of Resource and Environmental Management, Simon Fraser University, Burnaby, British Columbia, Canada.

Harper, J. R., J. Haggarty, and M. C. Morris. 1995. Broughton archipelago clam terrace survey: final report. Coastal and Ocean Resources, Sidney, British Columbia, Canada.

Harris, D. C. 2008. Landing native fisheries: Indian reserves \& fishing rights in British Columbia, 1849-1925. University of British Columbia Press, Vancouver, British Columbia, Canada.

Heaslip, R. 2008a. Access protocols and social identity in Kwakwaka'wakw clam management: from colonialism to cultural revitalization. Thesis. School of Resource and Environmental Management, Simon Fraser University, Burnaby, British Columbia, Canada.

Heaslip, R. 2008b. Monitoring salmon aquaculture waste: the contribution of First Nations' rights, knowledge, and practices in British Columbia, Canada. Marine Policy 32(6):988-996. http:// dx.doi.org/10.1016/j.marpol.2008.02.002

Heclo, H. 1978. Issue networks and executive establishment. Pages 87-124 in A. Kind, editor. The new American political system. American Enterprise Institute, Washington, D.C., USA.

Holtby, B., and B. Finnegan. 1997. A biological assessment of the Coho salmon of the Skeena River, British Columbia, and recommendations for fisheries in 1998. Canadian Stock Assessment Secretariat. Research Document 97/138. Fisheries and Oceans Canada, Pacific Biological Station, Stock Assessment Division, Nanaimo, British Columbia, Canada.

Inglis, R., and G. MacDonald. 1979. Skeena River prehistory. Volume 87 of Archaeological Survey of Canada Paper Mercury Series. National Museums of Canada, Ottawa, Ontario, Canada.

Jones, R., M. Shepert, and N. J. Sterritt. 2004. Our place at the table: First Nations in the B.C. fishery. First Nation Panel on Fisheries, Vancouver, British Columbia, Canada.

Kretzmann, J. P., and J. L. McKnight. 1993. Building communities from the inside out: a path toward finding and mobilizing a community's assets. The Asset-Based Community Development Institute, School of Education and Social Policy, Northwestern University, Evanston, Illinois, USA.

Lane, D. E., and R. L. Stephenson. 2000. Institutional arrangements for fisheries: alternate structures and impediments to change. Marine Policy 24(5):385-393. http://dx.doi. org/10.1016/S0308-597X(00)00014-2

Langdon, S. 2007. Sustaining a relationship: inquiry into the emergence of a logic of engagement with salmon among the Southern Tlingits. Pages 233-276 in M. F. Harkin and D. R. Lewis, editors. Native Americans and the environment: perspectives on the ecological Indian. University of Nebraska Press, Lincoln, Nebraska, USA.

Lepofsky, D. 2009. The past, present, and future of traditional resource and environmental management. Journal of Ethnobiology 29(fall/winter):161-166.

Lyons, C. 1969. Salmon our heritage: the story of a province and an industry. British Columbia Packers, Vancouver, British Columbia, Canada.

Marchak, P., N. Guppy, and J. L. McMullan, editors. 1987. Uncommon property: the fishing and fish-processing industries in British Columbia. University of British Columbia Press, Vancouver, British Columbia, Canada.

Meggs, G. 1991. Salmon: the decline of the British Columbia fishery. Douglas and McIntyre, Vancouver, British Columbia, Canada.

Muckle, R. J. 2007. The First Nations of British Columbia: an anthropological survey. Second edition. University of British Columbia Press, Vancouver, British Columbia, Canada. 
Newell, D. 1993. Tangled webs of history: Indians and the law in Canada's Pacific coast fisheries. University of Toronto Press, Toronto, Ontario, Canada.

North, G. 1974. A ripple, a wave: the story of union organization in the B.C. fishing industry. Fisherman Publishing Society, Vancouver, British Columbia, Canada.

Ommer, R. E. 2007. Coasts under stress: restructuring and socialecological health. McGill-Queen's Press, Kingston and Montreal, Canada.

Ostrom, E. 1990. Governing the commons: the evolution of institutions for collective action. Cambridge University Press, New York, New York, USA. http://dx.doi.org/10.1017/CBO9780511807763

Pacific Regional Clam Management Committee. 2001. Meeting notes. Fisheries and Oceans Canada, Government of Canada, Ottawa, Canada.

Pacific Regional Clam Management Committee. 2007. Meeting notes. Fisheries and Oceans Canada, Government of Canada, Ottawa, Canada.

Pacific Salmon Commission and Joint Northern Boundary Technical Committee. 2011. U.S./Canada Northern boundary area 2010 salmon fisheries management report and 2011 preliminary expectations. Report TCNB (11)-1. Pacific Salmon Commission and Joint Northern Boundary Technical Committee, Vancouver, British Columbia, Canada.

Pacific Salmon Commission and Joint Northern Boundary Technical Committee. 2012. U.S./Canada Northern boundary area 2011 salmon fisheries management report and 2012 preliminary expectations: one vs. five MUs in Puget Sound and the interior Fraser. Report TCNB (12)-1. Pacific Salmon Commission and Joint Northern Boundary Technical Committee, Vancouver, British Columbia, Canada.

Pinkerton, E. 1987. Indians in the fishing industry. Pages 249-269 in P. Marchak, N. Guppy, and J. L. McMullan, editors. Uncommon property: the fishing and fish-processing industries of British Columbia. University of British Columbia Press, Vancouver, British Columbia, Canada.

Pinkerton, E. 1989. Attaining better fisheries management through co-management: prospects, problems, and propositions. Pages 3-33 in E. Pinkerton, editor. Co-operative management of local fisheries: new directions in improved management \& community development. University of British Columbia Press, Vancouver, British Columbia, Canada.

Pinkerton, E. 1992. Translating legal rights into management practice: overcoming barriers to the exercise of co-management. Society for Applied Anthropology 51(4):330-341.

Pinkerton, E. 1993. Analyzing co-management efforts as social movements: the Tin-Wis Coalition and the drive for forest practice legislation in British Columbia. Alternatives 19(3):33-38.

Pinkerton, E. 1996. The contribution of watershed-based multiparty co-management agreements to dispute resolution: the Skeena Watershed Committee. Environments 23(2):51-68.

Pinkerton, E. 2007. Integrating holism and segmentalism: overcoming barriers to adaptive co-management between management agencies and multi-sector bodies. Pages 151-171 in D. Armitage, F. Berkes, and N. Doubleday, editors. Adaptive comanagement: collaborative learning and multi-level governance. University of British Columbia Press, Vancouver, British Columbia, Canada.

Pinkerton, E. 2009. The Skeena Watershed partnership: learning from success and failure. Pages 903-919 in C. C. Krueger and C. E. Zimmerman, editors. Pacific salmon: ecology and management of western Alaska's populations. American Fisheries Society Symposium 70. American Fisheries Society, Bethesda, Maryland, USA.

Pinkerton, E., and L. John. 2008. Creating local management legitimacy. Marine Policy 32(4):680-691. http://dx.doi.org/10.1016/ j.marpol.2007.12.005

Pinkerton, E., and M. Weinstein. 1995. Fisheries that work: sustainability through community-based management. David Suzuki Foundation, Vancouver, British Columbia, Canada. [online] URL: http://www.davidsuzuki.org/publications/downloads/1995/ Fisheries that Work web.pdf.

Poncelet, E. C. 2001. The discourse of environmental partnerships. Pages 273-292 in C. L. Crumley, editor. New directions in anthropology and the environment. AltaMira, Walnut Creek, California, USA.

Rajala, R. A. 2006. Up-coast: forests and industry on British Columbia's north coast, 1870-2005. Royal British Columbia Museum, Victoria, British Columbia, Canada.

Rohner, R. P. 1967. The people of Gilford: a contemporary Kwakiutl village. National Museum of Canada Bulletin No. 225. Anthropological Series No. 83. Queen's Printer, Ottawa, Ontario, Canada.

Schlager, E., and E. Ostrom. 1993. Property-rights regimes and coastal fisheries: an empirical analysis. Pages 13-41 in T. L. Anderson and R. T. Simmons, editors. The political economy of customs and culture: informal solutions to the commons problem. Rowman \& Littlefield, Lanham, Maryland, USA.

Schwindt, R., A. R. Vining, and D. Weimer. 2003. A policy analysis of the BC salmon fishery. Canadian Public Policy 29 (1):73-94. http://dx.doi.org/10.2307/3552489

Sharp, S. B., and D. Lach. 2003. Integrating social values into fisheries management: a Pacific Northwest study. Fisheries 28 (4):10-15. http://dx.doi.org/10.1577/1548-8446(2003)28[10:ISVIFM] 2.0.CO 2

Sinclair, P. 2012. Labour markets and livelihoods in threatened fishing communities. Session C5. Rebuilding collapsed fisheries and threatened communities - international symposium. Bonne Bay, Newfoundland and Labrador, October 1-4, 2012. Community-University Research for Recovery Alliance, Bonne Bay, Newfoundland and Labrador, Canada.

Sinclair, W. F. 1971. The importance of the commercial fishing industry to selected remote coastal communities of British Columbia. Department of the Environment, Fisheries Service, Pacific Region, Vancouver, British Columbia, Canada.

Skeena Watershed Committee. 1996. Facing and forming the future. Workshop proceedings, January 1996. Volume 19. Skeena 
Watershed Committee, Prince Rupert, British Columbia, Canada.

Thorkelson, J. 2012. Sustainable marine fisheries and communities alliance. Presentation to the Canadian Council of Professional Fish Harvesters. February 2012. Canadian Council of Professional Fish Harvesters, Vancouver, British Columbia, Canada.

Turner, N. J., F. Berkes, J. Stephenson, and J. Dick. 2013. Blundering intruders: extraneous impacts on two indigenous food systems. Human Ecology 41(4):563-574. http://dx.doi.org/10.1007/ s10745-013-9591-y

Walters, C. J., J. A. Lichatowich, R. M. Peterman, and J. D. Reynolds. 2008. Report of the Skeena independent science review panel. Submitted to the Department of Fisheries and Oceans \& the British Columbia Ministry of the Environment. 15 May. [online] URL: http://www.psf.ca/pdf/ISRP-final.pdf.

Williams, J. 2006. Clam gardens: Aboriginal mariculture on Canada's West Coast. Volume 15 of Transmontanus Series. New Star Books, Vancouver, British Columbia, Canada.

Wilson, D. C., J. R. Nielsen, and P. Degnbol, editors. 2003. The fisheries co-management experience: accomplishments, challenges and prospects. Fish \& fisheries series. Volume 26. Springer Science+Business Media, Dordrecht, Netherlands. http://dx.doi. org/10.1007/978-94-017-3323-6

Wilson, J. A, J. M. Acheson, M. Metcalfe, and P. Kleban. 1994. Chaos, complexity and community management of fisheries. Marine Policy 18(4):291-305. http://dx.doi.org/10.1016/0308-597X (94)90044-2

Wright, M. 2010. Aboriginal gillnet fishers, science, and the state: salmon fisheries management on the Nass and Skeena rivers, British Columbia, 1951-1961. Journal of Canadian Studies 44 (1):5-35.

Yaffee, S. L. 1997. Why environmental nightmares recur. Conservation Biology 11(2):328-337. http://dx.doi.org/10.1046/ j.1523-1739.1997.95204.x 